\title{
In memoriam: Paul G. Risser (1939-2014)
}

\author{
Louis R. Iverson - Scott Collins • \\ Jack Dangermond • Richard Forman • \\ Joan I. Nassauer · John Wiens • Erin Wolfe
}

Received: 5 February 2015/Accepted: 9 February 2015/Published online: 20 February 2015

(C) Springer Science+Business Media Dordrecht (outside the USA) 2015

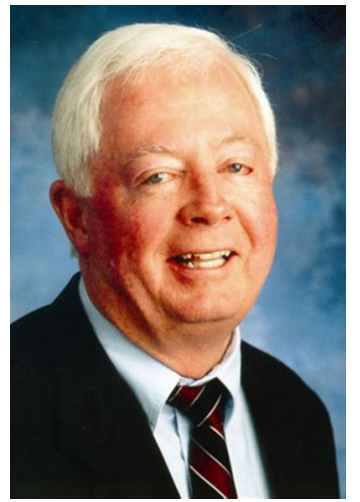

We lost a great one in ecology, an important person in the development of landscape ecology in North America and a gem of person on July 10, 2014. Paul

L. R. Iverson ( $\square)$

USDA Forest Service, Delaware, OH, USA

e-mail: liverson@fs.fed.us

S. Collins

University of New Mexico, Albuquerque, NM 87131,

USA

e-mail: scollins@sevilleta.unm.edu

J. Dangermond

ESRI, Redlands, CA, USA

e-mail: jdangermond@esri.com

R. Forman

Harvard University, Cambridge, MA 02138, USA

e-mail: rforman@gsd.harvard.edu continued to work in his office as much as he could throughout his many treatments for the decades-long illness that finally killed him, and was in his office until the week before he died. He leaves behind his wife Les, his twin brother, four sons, two daughters, and 14 grandchildren.

Paul G. Risser was born September 14, 1939 in Blackwell, Oklahoma, attended Grinnell College in Iowa (where he was serving as Vice Chair of the Board of Trustees at the time of his death), and earned M.S. (1965) and Ph.D. degrees (1967) from the University of Wisconsin, Madison. From there, he joined the University of Oklahoma, Norman, faculty of Botany, where he served as Director of the Oklahoma Biological Survey for 7 years and Chairman of the Department for 5 (with a stint at NSF as Program

\section{J. I. Nassauer}

University of Michigan, Ann Arbor, MI 48109, USA

e-mail: nassauer@umich.edu

\section{J. Wiens}

Oregon State University, Corvallis, OR 97330, USA

e-mail: jwiens300@gmail.com

E. Wolfe

University of Oklahoma, Norman, OK 73072, USA

e-mail: ewolfe@ou.edu 
Director of Ecosystem Studies). In 1981, he became Chief of the Illinois Natural History Survey, and in 1986 he joined the University of New Mexico as Vice President for Research, and eventually Provost and VP for Academic Affairs. Not to stop there, he became president of Miami University, Ohio from 1993-1995, then president of Oregon State University from 1996-2003, and then Chancellor of the entire Oklahoma System of Higher Education from 2003-2006. From 2006, he was Chair and Chief Operating Officer of the Research Cabinet at the University of Oklahoma, Norman, and Executive Director of Oklahoma's economic development organization, with a stint as Acting Director of the Smithsonian National Museum of Natural History in 2007 (and was still on the Board of Trustees).

As Chair of the Research Cabinet, Paul was responsible for leading large-scale research initiatives on OU's three campuses. His skill of bringing people from disparate disciplines together to move forward toward a common goal led to many successful university-wide efforts to improve research, teaching, and learning. Additionally, his passion for the promotion of innovative teaching techniques was instrumental in the development of numerous active learning classrooms now in use throughout the system. His dedicated service to research and education was also apparent in his high-level service to professional societies: president of Southwestern Association of Naturalists (1978-1979), president of Ecological Society of America (1984-1985), and president of American Institute of Biological Sciences (1991-1992). He was a fellow of the American Association for the Advancement of Science and the American Academy of Arts and Sciences.

John Wiens recalls: Paul and I were graduate students together at Wisconsin, he in Botany, me in Zoology. We shared interests, took classes together, and spent time in the field, me watching birds, Paul watching plants. We spent a good deal of time talking about how to bring the disciplines (and departments) closer together. Later, our academic paths ran in parallel for some years. But I remember visiting him at $\mathrm{OU}$ when he was department chair. We talked about the future, and he admitted that his real interest was in administration-that was how he felt he could be most effective in advancing science.
And he never looked back. But he also never lost his touch for science.

Paul's early career produced important plant ecophysiological papers-his first publication contributed to spruce tissue cultivation (published sole authored in Science, Risser 1964) followed by studies on environmental constraints on spring ephemerals (e.g., Risser and Cottam 1967), followed in turn by studies on allelopathic compounds on physiological traits of selected plants. In Oklahoma, he quickly established himself as an expert in plant diversity and community structure in forests and, especially, the tall grass prairie. He used a quantitative approach to assessing plant-soil relationships, which definitely looked like 'landscape ecology', especially when he used it to classify land, as a basis for selection of Biosphere Reserves (UNESCO Man and the Biosphere program, Risser and Cornelison 1979), and in systems analysis and simulations assessing the impact of management practices in grasslands (e.g., Parton and Risser 1980). He led a group that literally wrote the book on the 'True Prairie Ecosystem' (Risser et al. 1981), an experience that gave new meaning to the expression "herding cats", but Paul pulled it off. Paul and his students (e.g., Scott Collins, Jeff Klopatek, David Gibson) used landscape approaches to study bottomland forests, conduct energy analysis on forests and rangelands, and revegetation on mine spoils.

Collins recalls: Paul was a wonderful and forward thinking graduate mentor. In the late 1970s when most PhD programs were just about academics, he was training students to consider careers in federal agencies, NGOs, and environmental consulting firms. When I went to Oklahoma to work with him I was told I would need to be independent, self-motivated, and up on the literature. His office door was always open and he was always eager to discuss research ideas. In class he began each session by listing 2-3 references on the board relevant to the lecture topic with the expectation that we would track down these articles and be familiar with them. In those days that meant going to the library and photocopying those articles. He was open to a wide variety of research topics and ideas; the only restriction he placed on me was that my research must have something to do with 
plants! So I ended up working on the plant ecology of wood warblers during the breeding season in Minnesota and Maine. I was at Oklahoma during the late 1970s when he first started thinking about what he then called "regional" ecology. My grad student colleague, Dwight Adams, and I were supported on RAs to work on the regional ecology of Oklahoma. We used several databases available at the time (in print) to plot changes in various environmental parameters at the county scale. The maps we created were colorful, but I can't recall if they were really very meaningful. But this effort exposed me to larger-scale thinking about ecological concepts and human impacts on the environment, and I think this effort led to his more formal contributions to the development of Landscape Ecology.

His interest in landscape ecology emerged in full force in 1983. While at the Illinois Natural History Survey (INHS), Paul, Jim Karr and Richard Forman obtained NSF funding to bring 25 scholars from across the globe together to consider the potential of landscape ecology, then a European geography-ecology combination, as a promising frontier in North America.

Forman recalls from that time: After the first day when these leaders highlighted their separate disciplines and contributions, Paul fretted, "Could we have invited too diverse a group? Why weren't promising overlaps and synergies introduced? We can't lose this meeting. We MUST grab the moment!" Forman, who had interacted for two years with the European landscape ecologists, had it easy leading the second day, because the group, sensing Paul's concern, quickly began tentative but crucial steps in articulating interesting conceptual overlaps and promising tractable frontiers. Paul couldn't wait to lead the final morning session, when his gentle hand and mind led to a cascade of synergies and forward-thinking conclusions. Later, Forman often said that no-one topped Paul's ability to sense the most important ideas in a meeting, pinpoint areas of potential agreement, and articulate a forward-looking synthesis, which left many in awe and most ready to sign on right there.
This Allerton Workshop resulted in a seminal document "Landscape ecology-directions and approaches" (Risser et al. 1984) which initiated formal recognition of the science in North America and beyond, and increased the ecological contributions to the science. This keystone workshop marks the beginning of landscape ecology in North America, and has been revisited at several points since (Risser 1995a; Risser 1998; Risser and Iverson 2013; Wiens 2008; Wu 2013). The Allerton workshop crystallized landscape ecology with a conceptual base that has now become embedded in many disciplines and serves as a framework on which to bring together participants from disparate fields for which landscape heterogeneity or spatial and temporal scales are key to understanding and management. Each of the participants of the workshop (including a rookie named Iverson) went on to advance the science in their own ways since.

From 1986-1989 he served on the first executive team of the fledgling US-Chapter of the International Association for Landscape Ecology, along with the likes of Jerry Franklin, John Wiens, Joan Nassauer, William Romme, Monica Turner, and David Sharp. Paul gave the opening address "Landscape ecology: state of the art" at the first US-IALE symposium in 1986, when US-IALE was organized. These folks set the chapter on great footings where it quickly became the largest and most influential chapter of IALE. Paul also delivered a keynote "Should landscape ecology only change at the margin" in 1996, well after he was embroiled in university presidential 'stuff'. He was given the US-IALE Distinguished Landscape Ecologist award in 2000.

Nassauer recalls: The way in which Paul Risser, Jim Karr and Richard Forman articulated the foundations of landscape ecology in America in the 1984 Allerton report has been essential to subsequent socio-environmental approaches to science. The landscape ecology they described has been a foundation for my own work ever since the 1986 meeting where we formed the US-IALE Chapter. Not only did they spell out the importance of landscape pattern for understanding process, they insisted on the centrality of human agency in making landscapes. This was groundbreaking in American ecology. It opened the way for transdisciplinary work in landscapes around the world, anticipated our 
now familiar understanding that we live in a world dominated by humans, and invited social sciences, design, and planning into the science of landscape ecology.

I knew Paul as an inventive and accomplished ecologist of generously open intellect. He shared this quality with the handful of other leading ecologists who prompted landscape ecology to be established as an influential scientific approach in America. I vividly remember a drive that Paul, Richard Forman, and I made to a US-IALE field trip site at the 1990 meeting in Ohio. I was very much the junior person, learning by listening. While it was a short journey, Paul and Richard had an animated conversation about the potential for NSF Long Term Ecological Research sites to incorporate humans in the ecosystems studied. Their lively sense of possibility reinforced my sense that I, a social scientist designer, could make a contribution to the field. My hope is that landscape ecology continues to embody the combination of rigor with intellectual openness that echoed through that conversation and characterized Paul's work.

It was also in the early 1980s that GIS and large database management were emerging as valuable tools in landscape ecological studies. Paul, as Chief of the Natural History Survey, successfully acquired funding for a large project called 'The Lands Unsuitable for Mining Program', affectionately called 'LUMP'. This project brought together several scientists from different disciplines, along with only the $12^{\text {th }}$ installation of ESRI's ArcInfo software and the automation of many ecological and geological layers into 'integrated terrain unit' maps. Paul also promoted the automation and GIS-integration of large databases on all Illinois vertebrates (Illinois Fish and Wildlife Information System) and flora (Illinois Plant Information Network, www.nrs.fs.fed.us/ilpin, Iverson and Prasad 1998). These integrated databases became critical to landscape assessments such as a statewide assessment of land use change related to landscape attributes (Iverson and Risser 1987; Iverson 1988) and many other natural resource issues (Risser and Iverson 1988, Iverson et al. 1989). Paul was a true visionary in recognizing the value of putting GIS in the hands of landscape scientists.
Dangermond recalls: Paul was one of the first to recognize the value of GIS in Ecology and Geoscience. He supported and was the executive sponsor of the State of Illinois vision for creating a Statewide GIS. This was in the early days of ESRI. His leadership in both the science and application worlds established a pattern for regional and statewide environmental planning. The enormous impact of this is now well documented.

Paul then contributed to wider societal issues concerning ecology, largely stemming from his leadership roles in scientific societies: the importance for ecologists to engage in advancing biological literacy (Risser 1986), an Ecological Society of America perspective on the release of genetically engineered organisms (Mooney and Risser 1989), the importance of long-term ecological research (Risser 1991), making ecological information practical for resource managers (Risser 1993), and the Sustainable Biosphere Initiative (Lubchenco et al. 1991). Simultaneously, he became a leader in the understanding and management of ecotones (e.g., Holland et al. 1991; Risser 1995b).

As university Vice President, president, or chancellor, Paul had immense influence on the directions of research and education. He always supported both, and pushed for teaching students to use information "that has the readily apparent potential for improving the quality of life" (Risser 1986). In one published 'welcoming' (Risser 2001) to an initial symposium on ecological and societal aspects of transgenic plantations, Paul stated "Among the most significant values of great universities is the ability to bring together the best minds from many disciplines, and to focus these intellectual abilities on complex topics of particular importance to society. This intellectual pursuit must be accompanied by great attention to the ethical dimensions of the issue, and must encompass multiple perspectives supported by careful and thoughtful analyses. Moreover, these deliberations must be tested by peers and communicated to interested and affected constituencies. Your challenge here will require rising to the standards and expectations of great universities. You must consider both the potential benefits and risks to our forests from this technology, you must do so in the context of a world that is growing hungrier for resources, and you must 
consider our shared responsibility for the health of our biosphere."

Not only was Paul an excellent scientist and administrator, he was a true joy to work with and to be around. He was always ahead of his time, and it was inspiring to be around someone so intellectually uninhibited. Even when health issues were raging, he maintained a positive and congenial attitude. He would make time for all sorts of people who sought him out for advice and consultation. He had an incredible ability to quietly take disparate and often disjointed comments from a host of committee members and synthesize them into an elegant and forwardmoving plan. He enjoyed dancing and music and family and friends. His laugh was contagious.

Paul Risser touched and influenced many thousands of people, including those of us writing this memorial. Those thousands are carrying on with his ideas and ideals to the next generations. He had an enduring influence on the direction and impact of ecology, and especially landscape ecology. He did great things with humility, humor, grace, and a true drive to make the world a better place. You certainly did that Paul, and you will be missed!

\section{References}

Holland MM, Risser PG, Naiman RJ (eds) (1991) The role of landscape boundaries in the management and restoration of changing environments. Chapman and Hall, New York

Iverson LR (1988) Land-use changes in Illinois, USA: the influence of landscape attributes on current and historic use. Landscape Ecol 2:45-61

Iverson LR, Prasad A (1998) Estimating regional plant biodiversity with GIS modeling. Divers Distrib 4(2):49-61

Iverson LR, Risser PG (1987) Analyzing long-term changes in vegetation with geographic information system and remotely sensed data. Adv Space Res 7(11):183-194

Iverson LR, Oliver RL, Tucker DP, Risser PG, Burnett CD, Rayburn RG (1989) Forest resources of Illinois: an atlas and analysis of spatial and temporal trends. Illinois Department of Energy and Natural Resources, Illinois Council on Forestry Development, Champaign

Lubchenco J, Olson A, Brubaker L, Carpenter S, Holland M, Hubell S, Levin S, MacMahon J, Matson P, Melillo J, Mooney H, Peterson C, Pulliam H, Real R, Regal P, Risser $P$ (1991) The sustainable biosphere initiative: an ecological research agenda. Ecology 72:371-412
Mooney HA, Risser PG (1989) The release of genetically engineered organisms: a perspective from the Ecological Society of America. Ecology 70:297-298

Parton WJ, Risser PG (1980) Impact of management practices on the tallgrass prairie. Oecologia 46:223-234

Risser PG (1964) Somatic mitosis in cells of Picea glauca cultivated in vitro. Science 143:591-592

Risser PG (1986) Address of the past president: syracuse, New York; August 1986: ecological literacy. Bull Ecol Soc Am 67:264-270

Risser PG (ed) (1991) Long-term ecological research: an international perspective. Wiley, Chichester

Risser PG (1993) Making ecological information practical for resource managers. Ecol Appl 3:37-38

Risser PG (1995a) The Allerton Park workshop revisited-a commentary. Landscape Ecol 10(3):129-132

Risser PG (1995b) The status of the science examining ecotones. Bioscience 45(5):318-325

Risser PG (1998) Landscape ecology_does the science only need to change at the margin? In: Klopatek J, Gardner R (eds) Landscape ecological analysis: issues and applications. Springer-Verlag, New York

Risser PG (2001) Welcome to the first international symposium on ecological and societal aspects of transgenic plantations, in conjunction with the IUFRO conference on tree biotechnology in the new millennium. In: Strauss SH, Bradshaw HD (eds) Proceedings, international symposium on ecological and societal aspects of transgenic plantations, Oregon State University, Corvallis

Risser PG, Cornelison K (1979) Man and the biosphere. University of Oklahoma Press, Norman

Risser PG, Cottam G (1967) Influence of temperature on the dormancy of some spring ephemerals. Ecology 48:500-503

Risser PG, Iverson LR (1988) Geographic information systems and natural resource issues at the state level. In: Botkin DB, Caswell ME, Estes JE, Orio AA (eds) Our role in changing the global environment: what we can do about large scale environmental issues. Academic Press, New York, pp 231-239

Risser PG, Iverson LR (2013) 30 years later-landscape ecology: directions and approaches. Landscape Ecol 28(3):367-369

Risser PG, Birney EC, Blocker HD, May WS, Parton WJ, Wiens JA (1981) The true prairie ecosystem. Hutchinson and Ross Publishers, Stroudsburg

Risser PG, Karr JR, Forman RTT (1984) Landscape ecologydirections and approaches. INHS special publication Number 2, Champaign

Wiens J (2008) Allerton Park 1983: the beginnings of a paradigm for landscape ecology? Landscape Ecol 23(2): $125-128$

Wu J (2013) Key concepts and research topics in landscape ecology revisited: 30 years after the Allerton Park workshop. Landscape Ecol 28(1):1-11 